\title{
Article \\ Petroleum Hydrocarbon Composition of Oily Sludge and Contaminated Soils in a Decommissioned Oilfield Waste Pit under Desert Conditions
}

\author{
Hamad Al-Mebayedh ${ }^{1}$, Anyi Niu ${ }^{1,2, *(D)}$ and Chuxia Lin ${ }^{1,3, *}$ \\ 1 School of Science, Engineering and Environment, University of Salford, Greater Manchester, \\ Salford M5 4WT, UK; hmubayedh@kockw.com \\ 2 School of Geography, South China Normal University, Guangzhou 510631, China \\ 3 Faculty of Science, Engineering and Built Environment, Deakin University, Burwood, VIC 3125, Australia \\ * Correspondence: niuanyi@m.scnu.edu.cn (A.N.); chu.lin@deakin.edu.au (C.L.)
}

Citation: Al-Mebayedh, H.; Niu, A.; Lin, C. Petroleum Hydrocarbon Composition of Oily Sludge and Contaminated Soils in a

Decommissioned Oilfield Waste Pit under Desert Conditions. Appl. Sci. 2022, 12, 1355. https://doi.org/ 10.3390/app12031355

Academic Editor: Itzhak Katra

Received: 16 December 2021

Accepted: 26 January 2022

Published: 27 January 2022

Publisher's Note: MDPI stays neutral with regard to jurisdictional claims in published maps and institutional affiliations.

Copyright: (C) 2022 by the authors. Licensee MDPI, Basel, Switzerland. This article is an open access article distributed under the terms and conditions of the Creative Commons Attribution (CC BY) license (https:// creativecommons.org/licenses/by/ $4.0 /)$.

\begin{abstract}
Field and laboratory investigations were conducted to characterize the composition of petroleum hydrocarbons in oily sludge and the underlying contaminated soils in a decommissioned oilfield waste pit in Kuwait. The results show that the petroleum hydrocarbon composition in the oily sludge and contaminated soils was spatially variable. Highly toxic petroleum hydrocarbon species such as BTEX and PAHs were generally lacking, and both sludge- and soil-borne hydrocarbons were dominated by long-chain petroleum hydrocarbons. The soil contamination depth was generally very shallow although localized deep profiles $(>0.5 \mathrm{~m})$ were found. A loose relationship was established between TPH in the sludge and that in the underlying soil. On average, the soil had a greater percentage of shorter-chain hydrocarbon fractions (either aliphatics or aromatics), as compared to the sludge. The environmental risk from the oily sludge and contaminated soils is considered to be relatively low. For cost-effective management of the environmental risk of decommissioning an oilfield waste pit, containment of the sludge and contaminated soils using a soil-capping approach may be sufficient to minimize the possible adverse environmental impacts from the decommissioned waste pit, and this may represent an option that is superior to other costly remediation strategies.
\end{abstract}

Keywords: oily sludge; contaminated soils; oilfield; petroleum hydrocarbon; desert

\section{Introduction}

The petroleum industry generates substantial amounts of oily sludge during the exploitation, storage and refining of crude oil [1]. Oily sludge is a potentially hazardous material [2-4], which requires safe containment or treatment to minimize its adverse impacts on the environment [5-7]. Beneficial uses allow cost-effective management of oily sludge to be achieved [8]. To assess the environmental impacts of oily sludge and develop sound management strategies, it is necessary to understand the characteristics of oily sludge. Heidarzadeh et al. [9] investigated the characteristics of oily sludge from an oil refinery using parameters such as saturated alkanes, aromatics, non-hydrocarbons, resins and asphaltenes. Gopang et al. [10] characterized sludge deposits in crude oil storage tanks using the parameters of water, free oil and emulsion fractions. Imohimi et al. [11] assessed the characteristics of oily sludge from a refinery using parameters such as the total petroleum hydrocarbon (TPH), total volatile solids, oil and grease, dissolved oxygen (DO), five-day biological oxygen demand (BOD5) and chemical oxygen demand (COD).

Oilfield sludge pits are temporary storage facilities used for the disposal of oily wastes (drilling mud and cuttings) generated from drilling oil wells [4] or collecting crude oil due to emergency drill operation [12]. These facilities are exposed to an open environment. Unlike oily sludge generated in oil tanks or from crude oil processing, oily sludge in oilfield waste pits is formed via a strong interaction of the disposed of oil wastes with natural 
environmental factors such as solar radiation, atmospheric deposition and underlying soils. Volatile short-chain petroleum hydrocarbons in the oil wastes tend to evaporate rapidly. Photocatalytic degradation of petroleum hydrocarbons caused by solar radiation could also take place [13]. So far, detailed research work to characterize the oily sludge in oilfield sludge pits has been limited.

Crude oil contains various petroleum hydrocarbon species with different chemical structures and carbon numbers. At an equivalent carbon number, an aromatic hydrocarbon tends to be more toxic compared to its aliphatic counterpart [14]. For the same type of petroleum hydrocarbon, the smaller the carbon number, the more toxic it tends to be [15]. Therefore, the hazard of a given oily sludge is related to the composition of petroleum hydrocarbon compounds. For this reason, characterization of oily sludge based on parameters that provide no information on petroleum hydrocarbon speciation or fractionation - such as TPH, saturated alkanes, aromatics, resins, asphaltenes, free oil and emulsion fractions does not allow sensible assessment of the environmental risk associated with exposure to oily sludge.

During the storage of oil wastes in the oilfield waste pits, downward movement of oil fluid takes place, causing contamination of the underlying soils and potentially shallow aquifers [16]. Assessing the environmental risk of the contaminated soils and developing soil remediation strategies are also important parts of oilfield waste pit management. Investigation of soil contamination by petroleum has so far been focused on those formed following one-off oil spills $[17,18]$. The penetration depth of oil into soils depends on many factors such as characteristics of the penetrating oil, soil type, water input, etc. [19]. Oilfield waste pits are purpose-built structures frequently with a layer of compacted clay on the bottom to minimize the infiltration of oil fluid into the underlying soils. Unlike oil spill incidences, oilfield waste pits receive continuous oil input, and the soils beneath the oil wastes could experience oil penetration for an extended period. Therefore, it is expected that the characteristics of contaminated soils in oilfield waste pits differ from those caused by accidental oil spill events. However, there has so far been no detailed investigation into petroleum-contaminated soils in oilfield waste pits.

When decommissioning an oilfield waste pit, the relevant oil company has a legal responsibility to properly manage this abandoned facility and must meet regulatory requirements to minimize its impacts on the environment. Adequate knowledge of the petroleum hydrocarbon composition in the oily sludge and contaminated soils is, therefore, essential to inform cost-effective management of oilfield waste pits. In this study, a representative oilfield waste pit under desert conditions was investigated. The objectives were to (a) characterize the petroleum hydrocarbon composition of the oily sludge in the investigated waste pit, (b) understand how the oil wastes in the waste pit contaminate the underlying soil profiles and (c) highlight the implications of the research findings for cost-effective management of oilfield waste pits in areas with a similar climate.

\section{Materials and Methods}

\subsection{Study Site and Sampling Methods}

A typical oilfield waste pit within the Kuwait Oil Company (KOC) operating area in the southern Kuwait Burgan oilfields was selected for this study. The waste pit had a total area of about $90,000 \mathrm{~m}^{2}(300 \mathrm{~m} \times 300 \mathrm{~m})$. A grid sampling method was used to collect the oily sludge samples and underlying soil samples at each sampling location. The sludge pit was divided into 16 sampling grids $(75 \mathrm{~m} \times 75 \mathrm{~m}$ ), with the samples taken from the center of each grid. At each sampling location, a sludge sample was collected, followed by the collection of contaminated soil samples along the soil profile. After collection, each soil sample was split into two sub-samples and stored in two separate $170 \mathrm{~mL}$ glass jars that were packed into a plastic cooler with ice. The packed samples were then shipped to the laboratory for analysis. Sub-sample 1 was used to determine the BTEX (benzene, toluene, ethylbenzene and xylene) and polycyclic aromatic hydrocarbons (PAHs), and sub-sample 2 was used to determine various petroleum hydrocarbon fractions 


\subsection{Laboratory Methods}

A modified TPH CWG (TPH Criteria Working Group) method was used to determine the petroleum hydrocarbon fractions in the oily sludges and contaminated soils. Various petroleum hydrocarbons were extracted using dichloromethane. Sodium sulfate and silica were used for solution clean-up. The aliphatic and aromatic fractions were separated using solid-phase extraction techniques. Additional clean-up of the extract was performed by passing the solution through a membrane filter. The filtrate was treated with $15 \mathrm{~g}$ of acid silica in a clean round-bottomed flask placed on a rotary evaporator with no heat for $30 \mathrm{~min}$. The aliphatic fractions in the solution were then determined using capillary gas chromatography with the flame ionization detection (GC/FID) method.

BTEX in the oily sludge and soil samples were determined by headspace gas chromatography-mass spectrometry (GC/MS). The sample was heated and shaken vigorously. This carried the volatile components into the headspace of the extraction vessels. A certain volume of the headspace was sampled and passed onto the head of the gas chromatography (GC) column, which separated the different components. The eluent from the GC column passed into the ion source of a mass spectrometer, which recorded mass spectra continually at a regular interval and with unit mass resolution. Sixteen common polycyclic aromatic hydrocarbon species were also determined by headspace gas chromatography-mass spectrometry.

\subsection{Quality Assurance and Quality Control}

The analysis was performed in an accredited commercial analytical laboratory (Concept Life Sciences Analytical \& Development Services Limited, Manchester, UK). Analytical quality control was maintained by a number of measures, including multi-point calibration with set standards (with defined minimum performance characteristics), analysis of control samples within each analytical batch (such as versus independent standards, matrix spikes or reference materials), analysis of the reagent/method blanks within each analytical batch, ongoing quality assurance using control charts in conjunction with warning and action limits for the QC sample data and participation in external proficiency testing and inter-laboratory schemes such as the LGC Standards CONTEST and AQUACHECK. The concentrations of various petroleum hydrocarbons were expressed as the $\mathrm{mg} / \mathrm{kg}$ soil on a dry weight basis.

\section{Results and Discussion}

\subsection{Morphology of Sludge-Soil Profile}

In general, a layer of partially dry oily sludge ranging from 0.01 to $0.11 \mathrm{~m}$ was found across the investigated sludge pit (Figure 1). The thickness of the sludge layer varied markedly from location to location, probably reflecting the control of geomorphology on the distribution of oily wastes within the pit. Low-lying spots tended to hold more oil fluid above the land surface, resulting in a thicker layer of oily sludge on drying. The sludge layer was underlain by a layer of brownish sandy soil at most of the sampling locations, followed by uncontaminated soil at the bottom of the soil profiles. At most of the sampling locations, the thickness of the contaminated soil layer was limited to less than $0.1 \mathrm{~m}$, suggesting that penetration of crude oil into the soils was impeded. The soils with oil contamination to a depth greater than $0.45 \mathrm{~m}$ were only found at two locations (Figure 1). It is interesting to note that the thickness of the sludge layer was not related to the thickness of the contaminated soil layer. This suggests that the oil penetration depth was not determined by the amount of oil fluid overlying the soil. Oilfield waste pits are purpose-built structures to store drilling mud and oil spilled during oil production. A liner is usually used to minimize the penetration of oil fluid into the ground [20,21]. The limited number of deep contamination locations was probably the result of liner failure, leading oil to have seeped beyond the liner [22]. The findings here suggest that it is important to make sure that the quality of the liner is sufficient to avoid deep contamination of soils with the stored oil wastes from occurring. 


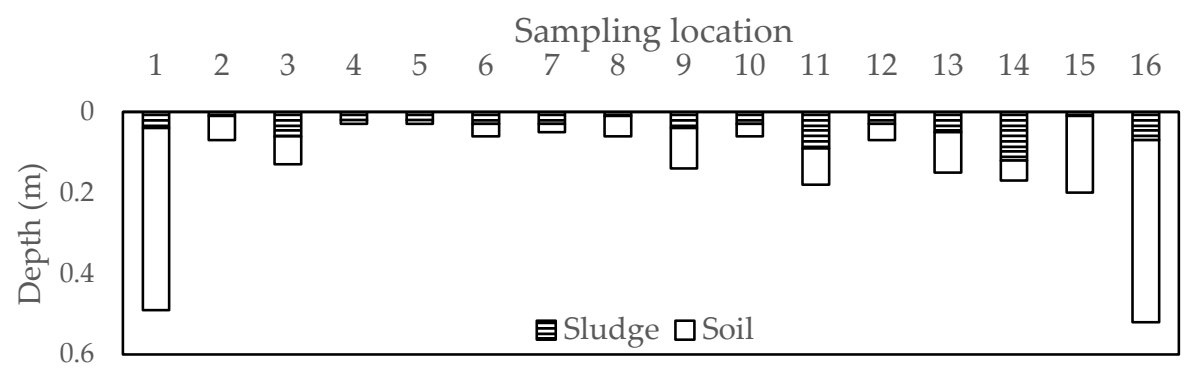

Figure 1. Graph showing the thickness of oily sludge and the underlying contaminated soil at the 16 sampling locations within the investigated oilfield waste pit.

\subsection{Petroleum Hydrocarbon Composition of the Oily Sludges}

No BTEX, aromatic petroleum hydrocarbon fractions with a carbon chain shorter than C12 or aliphatic hydrocarbons with a carbon chain length $<\mathrm{C} 16$ were detected from the collected oily sludge samples. This suggests that the volatile petroleum hydrocarbons had already been completely emitted to the atmosphere prior to sample collection. The predominant aliphatic petroleum hydrocarbon fraction was C21-C35 $(45,750 \pm 30,108 \mathrm{mg} / \mathrm{kg}, n=16)$ for all the investigated samples. The distribution of the three major fractions is given in Table 1.

Table 1. Concentrations $(\mathrm{mg} / \mathrm{kg}$ ) of aliphatic hydrocarbons in the oily sludge samples collected from the oilfield waste pit.

\begin{tabular}{cccc}
\hline Location & C16-C21 & C21-C35 & C35-C40 \\
\hline 1 & 2400 & 35,000 & 4400 \\
2 & 2500 & 31,000 & 3000 \\
3 & 20,000 & 110,000 & 12,000 \\
4 & 3700 & 36,000 & 4100 \\
5 & 1400 & 28,000 & 3500 \\
6 & 1100 & 33,000 & 3600 \\
7 & 1200 & 23,000 & 2300 \\
8 & 6600 & 33,000 & 3500 \\
9 & 7200 & 45,000 & 3900 \\
10 & 870 & 27,000 & 330 \\
11 & 8100 & 56,000 & 4800 \\
12 & 4500 & 35,000 & 3400 \\
13 & 3500 & 27,000 & 2800 \\
14 & 15,000 & 100,000 & 11,000 \\
15 & 920 & 13,000 & 1400 \\
16 & 14,000 & 100,000 & 11,000 \\
Mean & 5812 & 45,750 & 4689 \\
SD & 5808 & 30,108 & 3481 \\
\hline
\end{tabular}

No aromatic petroleum hydrocarbon fractions with carbon chains longer than C35 were detected from the 16 collected sludge samples. Fraction C21-C35 dominated the aromatic hydrocarbons. Fraction $\mathrm{C} 12-\mathrm{C} 16$ was present at a small amount or not detectable. The total aromatic hydrocarbon had a mean value of $12,461 \mathrm{mg} / \mathrm{kg}$ with a standard deviation of $7704 \mathrm{mg} / \mathrm{kg}$ (Table 2). 
Table 2. Concentrations $(\mathrm{mg} / \mathrm{kg}$ ) of aromatic hydrocarbons in the oily sludge samples collected from the oilfield waste pit.

\begin{tabular}{cccc}
\hline Location & C12-C16 & C16-C21 & C21-C35 \\
\hline 1 & 110 & 1500 & 7800 \\
2 & 130 & 1100 & 6400 \\
3 & 230 & 6200 & 24,000 \\
4 & 0 & 2000 & 9800 \\
5 & 0 & 850 & 6000 \\
6 & 0 & 1300 & 9200 \\
7 & 0 & 1100 & 7100 \\
8 & 0 & 2100 & 7500 \\
9 & 0 & 2400 & 9800 \\
10 & 0 & 790 & 7500 \\
11 & 0 & 2200 & 12,000 \\
12 & 0 & 1600 & 7700 \\
13 & 0 & 1400 & 6400 \\
14 & 270 & 4700 & 23,000 \\
15 & 0 & 510 & 2600 \\
16 & 180 & 3900 & 18,000 \\
Mean & 58 & 2103 & 10,300 \\
SD & 95 & 1559 & 6110 \\
\hline
\end{tabular}

There was a close relationship $\left(R^{2}=0.9469\right)$ between the total aliphatic hydrocarbon and the total aromatic hydrocarbon in the oily sludges (Figure 2). However, the ratio of total aromatic hydrocarbon to the total aliphatic hydrocarbon was around 0.2 , indicating that over $80 \%$ of the total petroleum hydrocarbon was in aliphatic forms. Park and Park [23] determined petroleum hydrocarbon fractions in two petroleum hydrocarbon-contaminated sites and found that the aliphatic fraction $\mathrm{C} 8-\mathrm{C} 16$ and aromatic fraction $\mathrm{C} 10-\mathrm{C} 21$ were the major contributors to human health risk via all the exposure routes. The pre-dominant aliphatic fractions and aromatic fractions were all C21-C35 in the investigated sludges, suggesting that these sludge materials were unlikely to pose a high risk to human health.

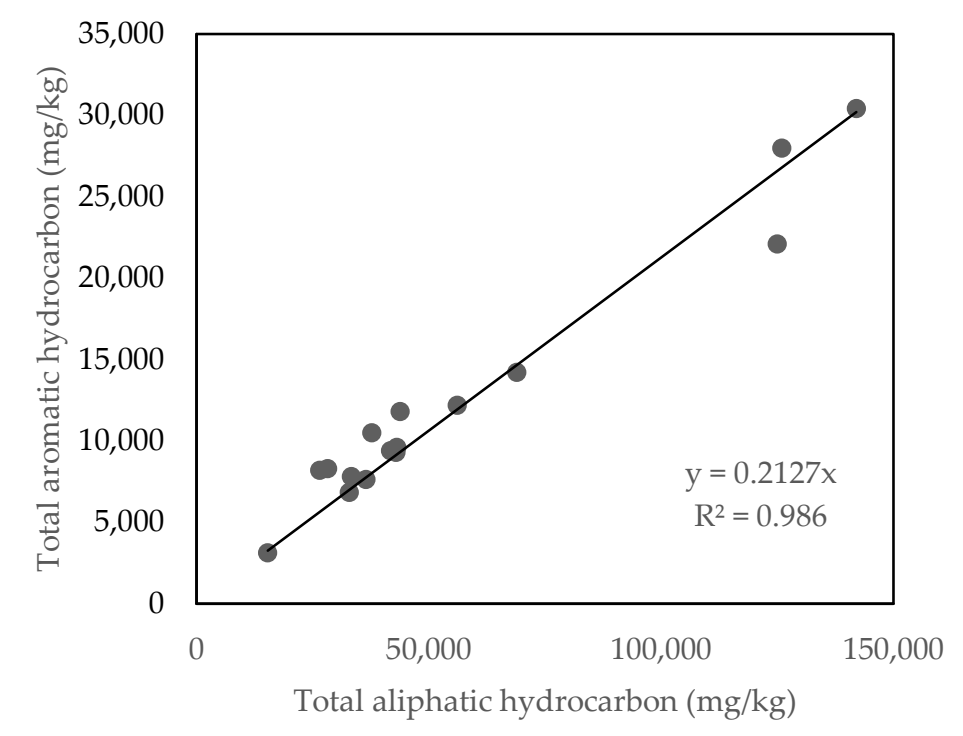

Figure 2. Relationship between the total aliphatic hydrocarbon and the total aromatic hydrocarbon in the sludge samples.

The total PAH in the sludge materials was only detected in 10 out of the 16 sampling locations with a very low value $(<20 \mathrm{mg} / \mathrm{kg})$. Only three PAH species were found in 
the sludge samples: chrysene, pyrene and phenanthrene (Table 3). Chrysene was the most common PAH species with its presence found in 8 out of the 16 sampling locations. Location 3 had the highest level of chrysene $(10 \mathrm{mg} / \mathrm{kg})$. Pyrene was only detected at Locations 1 and 6.

Table 3. Concentrations $(\mathrm{mg} / \mathrm{kg}$ ) of PAHs in the oily sludge samples collected from the oilfield waste pit.

\begin{tabular}{|c|c|c|c|c|c|c|c|c|c|c|}
\hline Sampling Location & 1 & 3 & 5 & 6 & 7 & 8 & 9 & 11 & 12 & 13 \\
\hline Naphthalene & $<1.0$ & $<1.0$ & $<1.0$ & $<1.0$ & $<1.0$ & $<1.0$ & $<1.0$ & $<1.0$ & $<1.0$ & $<1.0$ \\
\hline Acenaphthylene & $<1.0$ & $<1.0$ & $<1.0$ & $<1.0$ & $<1.0$ & $<1.0$ & $<1.0$ & $<1.0$ & $<1.0$ & $<1.0$ \\
\hline Acenaphthene & $<1.0$ & $<1.0$ & $<1.0$ & $<1.0$ & $<1.0$ & $<1.0$ & $<1.0$ & $<1.0$ & $<1.0$ & $<1.0$ \\
\hline Fluorene & $<1.0$ & $<1.0$ & $<1.0$ & $<1.0$ & $<1.0$ & $<1.0$ & $<1.0$ & $<1.0$ & $<1.0$ & $<1.0$ \\
\hline Phenanthrene & $<1.0$ & 5.2 & $<1.0$ & $<1.0$ & $<1.0$ & 2 & 1 & $<1.0$ & $<1.0$ & 1.2 \\
\hline Anthracene & $<1.0$ & $<1.0$ & $<1.0$ & $<1.0$ & $<1.0$ & $<1.0$ & $<1.0$ & $<1.0$ & $<1.0$ & $<1.0$ \\
\hline Fluoranthene & $<1.0$ & $<1.0$ & $<1.0$ & $<1.0$ & $<1.0$ & $<1.0$ & $<1.0$ & $<1.0$ & $<1.0$ & $<1.0$ \\
\hline Pyrene & 1.7 & $<1.0$ & $<1.0$ & 1 & $<1.0$ & $<1.0$ & $<1.0$ & $<1.0$ & $<1.0$ & $<1.0$ \\
\hline Benzo(a)anthracene & $<1.0$ & $<1.0$ & $<1.0$ & $<1.0$ & $<1.0$ & $<1.0$ & $<1.0$ & $<1.0$ & $<1.0$ & $<1.0$ \\
\hline Chrysene & $<1.0$ & 10 & 3.5 & 3.6 & 4.4 & 4.9 & 2.9 & 4.9 & 4.2 & $<1.0$ \\
\hline Benzo(a)pyrene & $<1.0$ & $<1.0$ & $<1.0$ & $<1.0$ & $<1.0$ & $<1.0$ & $<1.0$ & $<1.0$ & $<1.0$ & $<1.0$ \\
\hline Indeno(123-cd)pyrene & $<1.0$ & $<1.0$ & $<1.0$ & $<1.0$ & $<1.0$ & $<1.0$ & $<1.0$ & $<1.0$ & $<1.0$ & $<1.0$ \\
\hline Dibenzo(ah)anthracene & $<1.0$ & $<1.0$ & $<1.0$ & $<1.0$ & $<1.0$ & $<1.0$ & $<1.0$ & $<1.0$ & $<1.0$ & $<1.0$ \\
\hline Benzo(ghi)perylene & $<1.0$ & $<1.0$ & $<1.0$ & $<1.0$ & $<1.0$ & $<1.0$ & $<1.0$ & $<1.0$ & $<1.0$ & $<1.0$ \\
\hline Benzo(b)fluoranthene & $<1.0$ & $<1.0$ & $<1.0$ & $<1.0$ & $<1.0$ & $<1.0$ & $<1.0$ & $<1.0$ & $<1.0$ & $<1.0$ \\
\hline Benzo(k)fluoranthene & $<1.0$ & $<1.0$ & $<1.0$ & $<1.0$ & $<1.0$ & $<1.0$ & $<1.0$ & $<1.0$ & $<1.0$ & $<1.0$ \\
\hline
\end{tabular}

\subsection{Petroleum Hydrocarbon Composition of the Contaminated Soils}

TPH in the soils varied horizontally and vertically. The TPH in the surface soil layer ranged from 86 to $3350 \mathrm{mg} / \mathrm{kg}$ with a mean value of $1447 \mathrm{mg} / \mathrm{kg}$. Location $3 \mathrm{had}$ the highest level of TPH while Locations 1, 4, 5, 7 and 10 had TPH of less than $500 \mathrm{mg} / \mathrm{kg}$ (Figure 3).

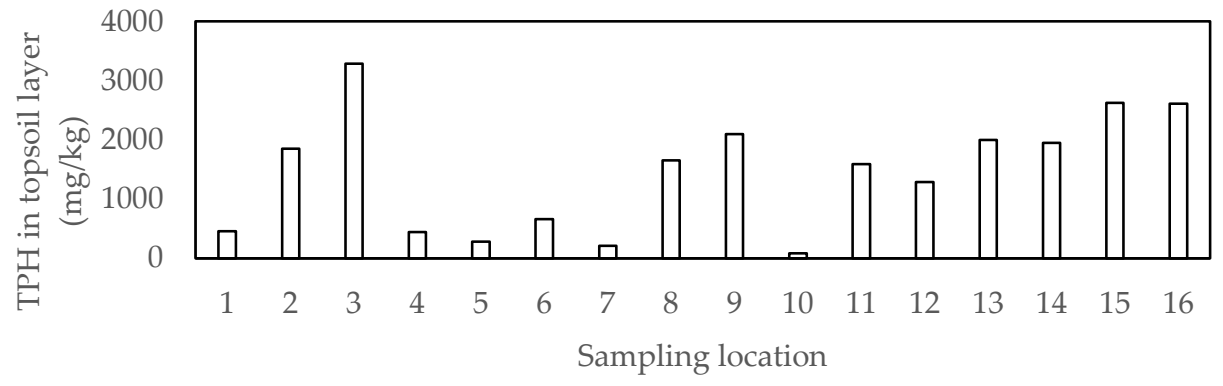

Figure 3. TPH in the surface soil layer $(0-5 \mathrm{~cm})$ for the 16 sampling locations.

The C21-C35 fraction dominated the aliphatic hydrocarbon fraction, followed by C16-C21, C35-C40, C12-C16 and C10-C12. Fractions with a carbon number of less than 10 were not detected (Figure 4a). For the aromatic hydrocarbons, fractions with a carbon number of less than 12 and more than 35 were not detected. The concentrations of the detectable aromatic petroleum hydrocarbon fractions progressed in the following decreasing order: C21-C35 > C16-C21 > C12-C16 (Figure 4b). 

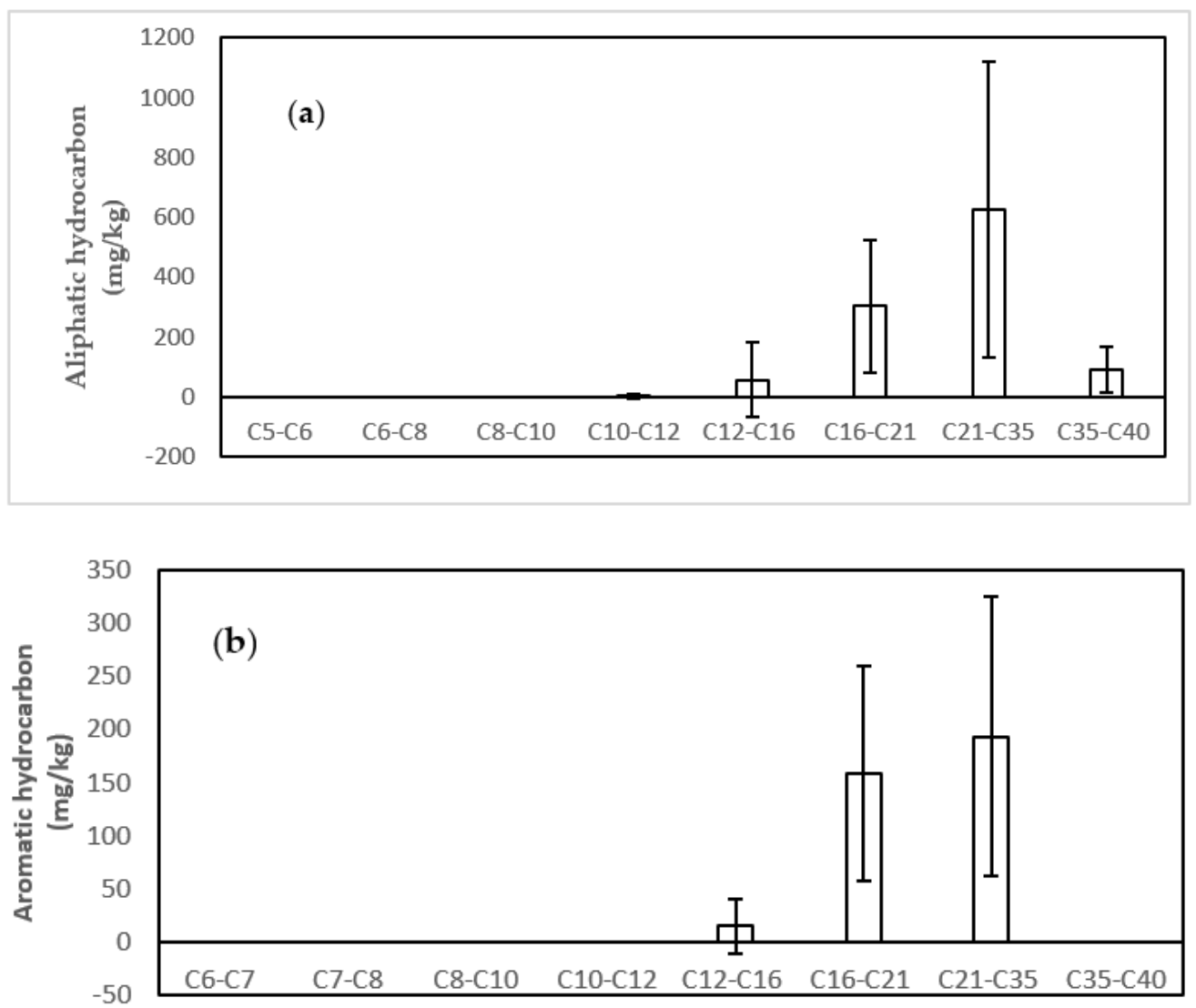

Figure 4. Distribution of various (a) aliphatic hydrocarbon fractions and (b) aromatic hydrocarbon fractions in the surface layer $(0-5 \mathrm{~cm})$ of the contaminated soil.

As mentioned in Section 3.1, the contamination depth was limited to less than $0.15 \mathrm{~m}$ with only two locations where an oil contamination depth of greater than $0.45 \mathrm{~m}$ was found, which possibly resulted from liner failure. Figure 5 shows the vertical variation in various aliphatic and aromatic hydrocarbon fractions along the soil profile at Location 16. It can be seen that the vertical variation pattern had a certain level of similarity between the aliphatic hydrocarbon and the aromatic hydrocarbon and between the different fractions for the same type of petroleum hydrocarbon (Figure 5). When there is a sufficient supply of oil fluid above soil, the oil tends to move downwards due to gravity and occupies soil pores. The concentration of petroleum hydrocarbons in a soil layer is, therefore, affected by the porosity of that soil layer. Soil with high porosity tends to accommodate more penetrating oil. Consequently, the soil has a higher concentration of petroleum hydrocarbons. The observed fluctuation in either the aliphatic or aromatic hydrocarbons along the soil profile suggests that the soil porosity varied vertically along the soil profile.

\subsection{Relationship between Sludge-Borne Hydrocarbon and Soil-Borne Hydrocarbon}

It is interesting to note that there was only a loose relationship in TPH between the oily sludge and the underlying surface soil layer for the 16 sampling locations (Figure 6). The differential spatial distribution pattern in TPH between the surface soil layer and the overlying oily sludge may be explained by two reasons. Firstly, the TPH concentration in the sludge was determined by the number of impurities present in the original crude oil and the incorporation of sediments from atmospheric deposition driven by the wind into the sludge. Moreover, the sludge pit received petroleum with different chemical compositions from different spill events and sediments at different amounts, and sludge derived from drilling mud tended to contain fewer petroleum hydrocarbons than that 
derived from spilled oil. Secondly, the porosity of the surface soil might vary horizontally, causing horizontal variation in soil-borne TPH.
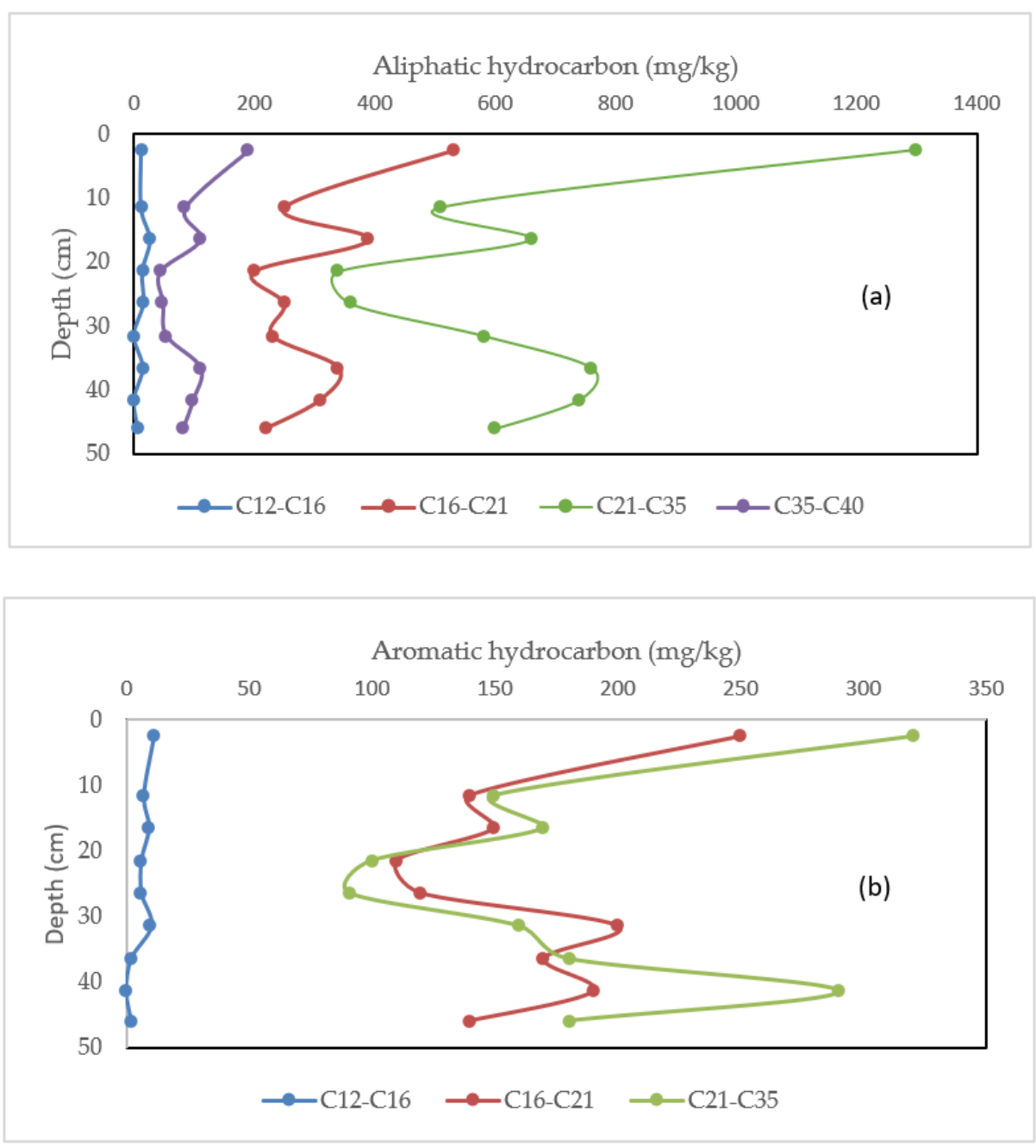

Figure 5. Changes in various (a) aliphatic hydrocarbon fractions and (b) aromatic hydrocarbon fractions along soil profile 16 .

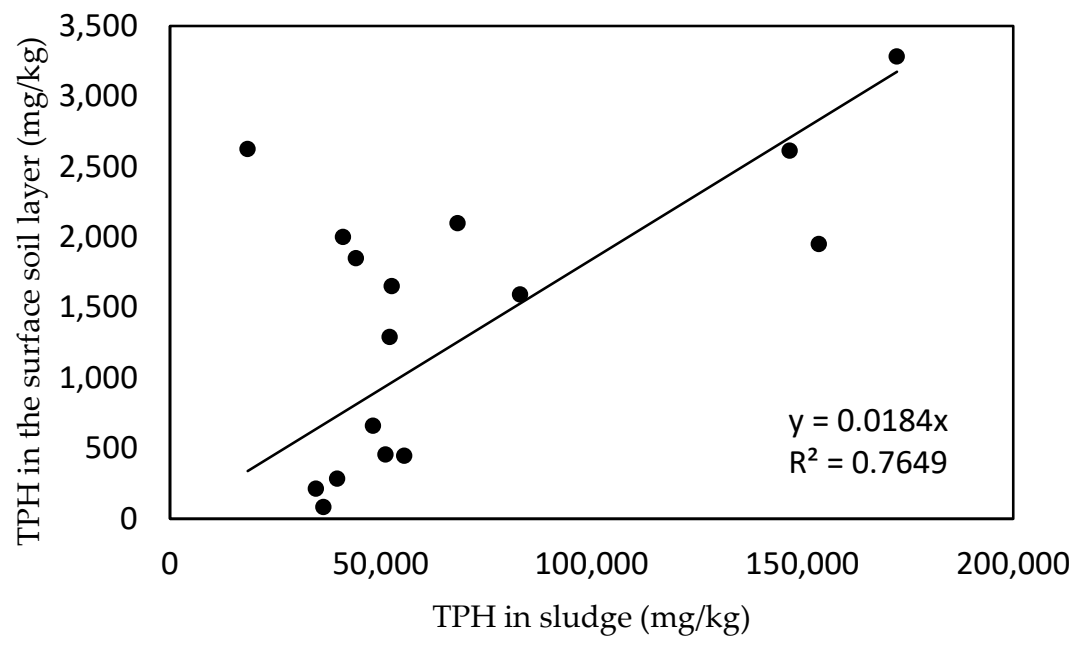

Figure 6. TPH relationship between the sludge and the underlying surface soil layer. 
Further analysis shows that the petroleum hydrocarbon composition differed between the sludge and the underlying soil. On average, the soil had a greater proportion of shorter-chain hydrocarbon fractions (either aliphatics or aromatics) compared to the sludge (Figure 7). This inconsistency reflects differential dissipation rates of the petroleum hydrocarbon fractions between the sludge and the soil. The volatility of petroleum hydrocarbons increased with increasing temperature [24,25]. The sludge was directly exposed to the atmosphere and received solar radiation. This favored the evaporation of semi-volatile hydrocarbon fractions, as compared to the soil-borne counterparts, which were trapped in soil pores via adsorption by soil particles [26].

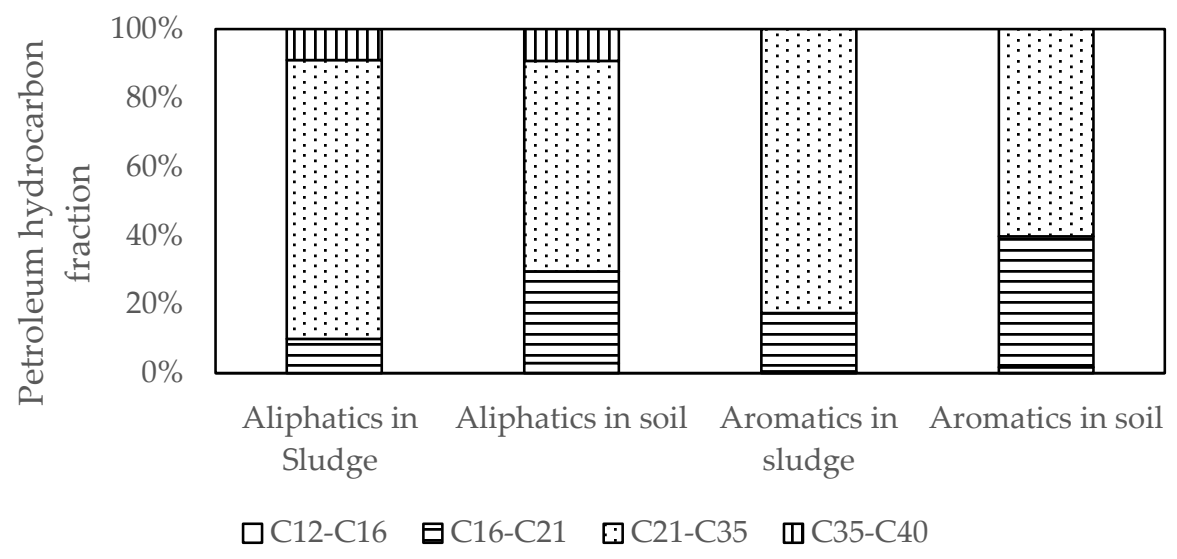

Figure 7. Petroleum hydrocarbon composition of the sludge and the underlying soil.

There was a poor relation of the aliphatic fraction of C16-C21 between the sludge and the surface soil layer $\left(\mathrm{R}^{2}=0.16\right)$ (Figure 8a). Although the relationship improved for the longer-chain hydrocarbon fractions (Figure $8 \mathrm{~b}, \mathrm{c}$ ), the $\mathrm{R}^{2}$ values were all less than 0.6. In comparison with aliphatic hydrocarbons, closer relationships between the sludge and the surface soil layer were observed for the aromatic hydrocarbon fractions. There was also a trend whereby the $\mathrm{R}^{2}$ increased with an increasing carbon number (Figure 9). Meanwhile, the poor relationship between the sludge and the soil for the semi-volatile shorter-chain hydrocarbon fractions was partially attributed to the differential dissipation rates via volatilization. The same phenomena could not be explained by this factor because the longer-chain hydrocarbon fractions were non-volatile. Therefore, it was likely that various hydrocarbon fractions did not migrate downwards proportionally due to differences in soil conditions between different locations.

\subsection{Implications for Management of the Oilfield Waste Pits in Desert Areas}

The research findings obtained from this study suggest that the environmental risk of the investigated oilfield waste pit was not significant. Under desert conditions, contamination of groundwater was unlikely, even when some localized liner failures took place. The oilfield was far away from human settlements. Therefore, the human health risk via ingestion and dermal contact is minimal. However, inhalation of petroleum hydrocarboncontaining dusts by oilfield workers is still likely, and it is necessary to take appropriate remedial action in order to reduce such a risk.

A range of remediation technologies have been used to treat petroleum hydrocarboncontaminated soils, including soil washing [27], thermal treatment [28], chemical treatment [29], bioremediation [30] and combined treatment methods [31,32]. Soil washing is ineffective for heavily contaminated soils. Although thermal treatment is highly effective, it is very costly. Given that degradation-resistant long-chain fractions dominated the petroleum hydrocarbons in the sludge and contaminated soils, eliminating the petroleum hydrocarbons via chemical treatment could be extremely costly. Bioremediation is costeffective in humid areas. However, the harsh environmental conditions encountered in 
deserts do not favor bioremediation due to low soil moisture contents, high salinity and an insufficient supply of nutrients. From an environmental remediation point of view, it may be more cost-effective to use a soil-capping approach to limit human contact with the oily sludge and contaminated soils.
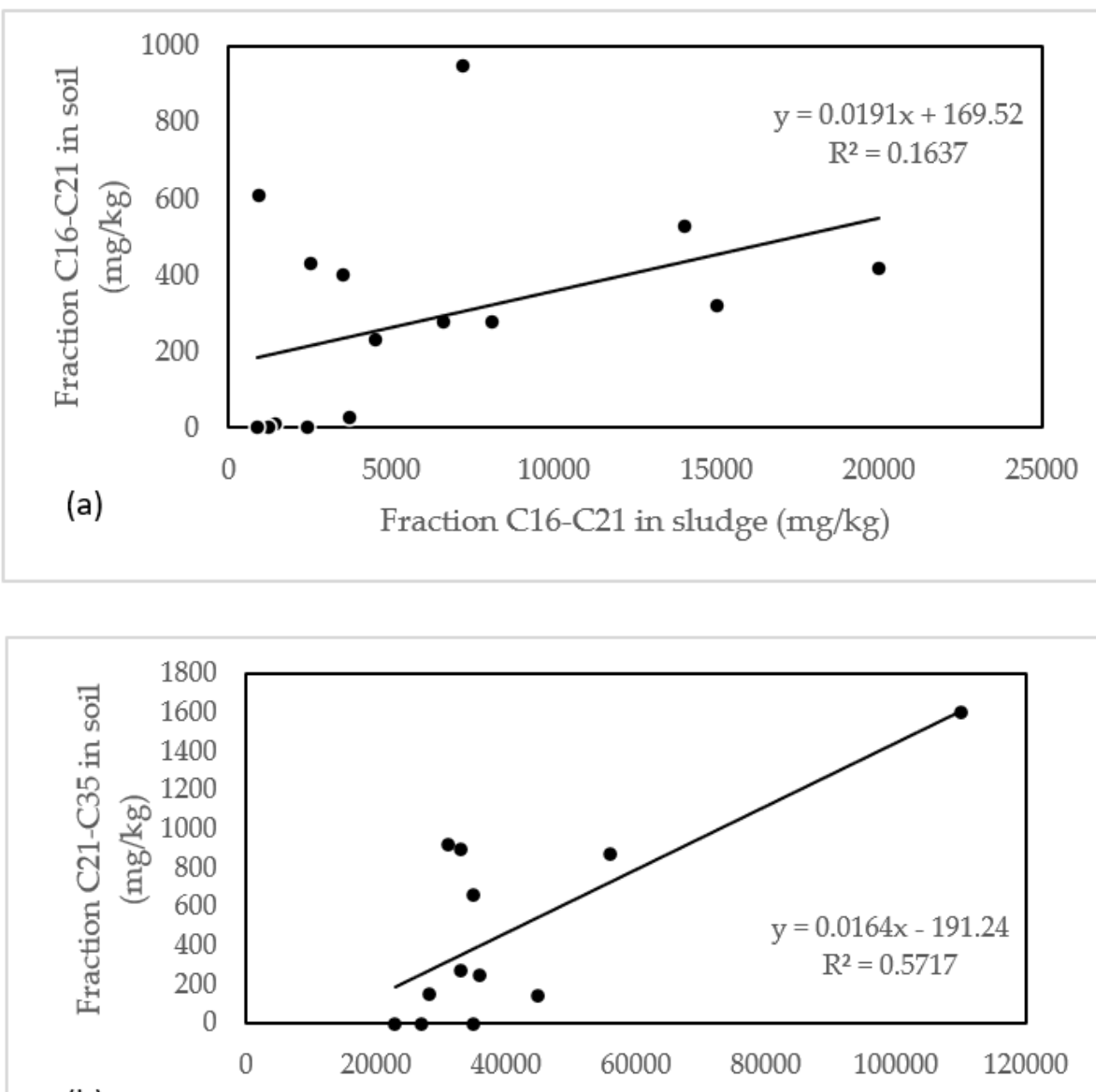

(b)

Fraction $\mathrm{C} 21-\mathrm{C} 35$ in sludge $(\mathrm{mg} / \mathrm{kg})$

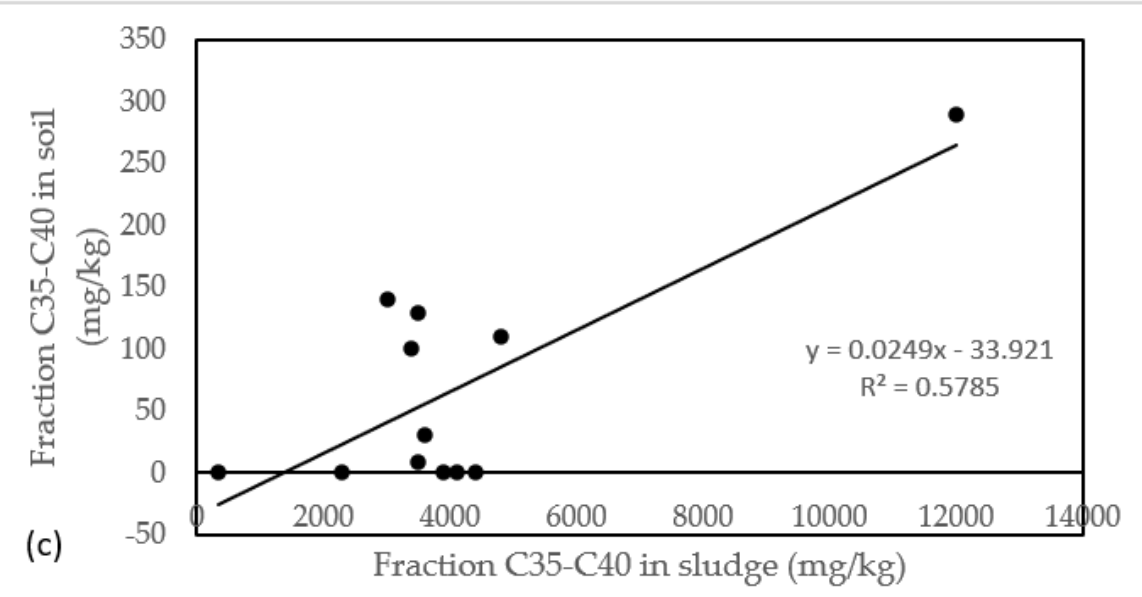

Figure 8. Relationship of aliphatic fractions (a) C16-C21, (b) C21-C35, and (c) C35-C40 between the sludge and the surface soil. 
(a)
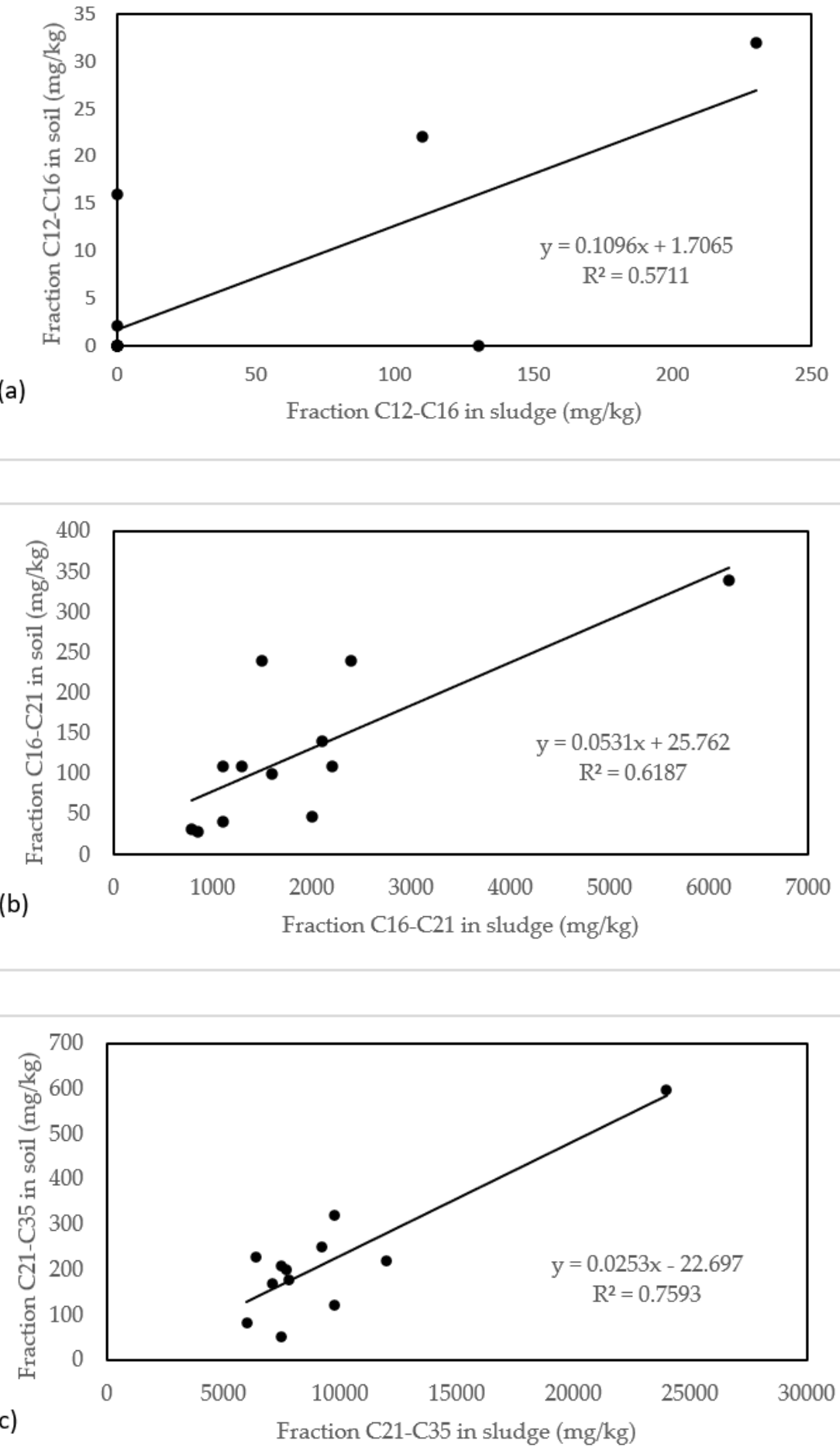

Figure 9. Relationship of aromatic fractions (a) C12-C16, (b) C16-C21, and (c) C21-C35 between the sludge and the surface soil.

\section{Conclusions}

The composition of petroleum hydrocarbons in the oily sludge and contaminated soils of the investigated oilfield waste pit varied spatially. Long-chain hydrocarbons dominated the petroleum hydrocarbons. Highly toxic BTEX and PAHs were not detected except for trace amounts of phenanthrene, pyrene and chrysene in some samples. The soil contamination depth was generally very shallow, although localized deep profiles 
$(>0.5 \mathrm{~m})$ were found. There was a loose relationship between the TPH in the sludge and that in the underlying soil. On average, the soil had a greater proportion of shorter-chain hydrocarbon fractions (either aliphatics or aromatics), as compared to the sludge, due to different dissipation rates of the shorter-chain hydrocarbons in the sludge and the soil. The environmental risk from the oily sludge and contaminated soils is relatively low. From an environmental remediation perspective, soil capping may be a cost-effective method for minimizing the environmental impacts of the decommissioned oilfield waste pits in desert areas that are not in close proximity to human settlements.

\begin{abstract}
Author Contributions: Conceptualization, C.L. and H.A.-M.; methodology, H.A.-M. and C.L.; investigation, H.A.-M. and A.N.; resources, C.L.; data curation, A.N.; writing-original draft preparation, A.N.; writing-review and editing, C.L.; visualization, A.N.; supervision, C.L.; project administration, C.L.; funding acquisition, H.A.-M. All authors have read and agreed to the published version of the manuscript.
\end{abstract}

Funding: This research was funded by a PhD scholarship from the Kuwait Petroleum Corporation and an international exchange PhD scholarship from the South China Agricultural University.

Institutional Review Board Statement: Not applicable.

Informed Consent Statement: Not applicable.

Data Availability Statement: Not applicable.

Acknowledgments: The authors thank the Kuwait Oil Company Soil Remediation Group for providing the oily sludge and soil samples.

Conflicts of Interest: The authors declare no conflict of interest.

\title{
References
}

1. Hui, K.; Tang, J.; Lu, H.; Xi, B.; Qu, C.; Li, J. Status and prospect of oil recovery from oily sludge: A review. Arab. J. Chem. 2020, 13, 6523-6543. [CrossRef]

2. Mazlova, E.; Meshcheryakov, S. Ecological characteristics of oil sludges. Chem. Technol. Fuels. Oil 2007, 35, 49-53. [CrossRef]

3. Wang, S.; Yan, Z.; Guo, G.; Lu, G.; Wang, Q.; Li, F. Ecotoxicity assessment of aged petroleum sludge using a suite of effects-based end points in earthworm Eisenia fetida. Environ. Monit. Assess. 2010, 169, 417-428. [CrossRef] [PubMed]

4. Gorlenko, N.V.; Timofeeva, S.S. Assessment of environmental damage from oil sludge to land resources in the Irkutsk region. IOP Conf. Ser. Earth Environ. Sci. 2019, 408, 012021. [CrossRef]

5. Leonard, S.A.; Stegemann, J.A. Stabilization solidification of petroleum drill cuttings: Leaching studies. J. Hazard. Mater. 2010, 174, 484-491. [CrossRef]

6. Da Silva, L.J.; Alves, F.C.; de França, F.P. A review of the technological solutions for the treatment of oily sludges from petroleum refineries. Waste. Manag. Res. 2012, 30, 1016-1030. [CrossRef]

7. Hu, G.; Li, J.; Zeng, G. Recent development in the treatment of oily sludge from petroleum industry: A review. J. Hazard. Mater. 2013, 261, 470-490. [CrossRef]

8. Hu, G.; Li, J.; Hou, H. A combination of solvent extraction and freeze thaw for oil recovery from petroleum refinery wastewater treatment pond sludge. J. Hazard. Mater. 2015, 283, 832-840. [CrossRef]

9. Heidarzadeh, N.; Gitipour, S.; Abdoli, M.A. Characterization of oily sludge from a Tehran oil refinery. Waste Manag. Res. 2010, 28, 921-927. [CrossRef]

10. Gopang, I.; Mahar, H.; Jatoi, A.; Akhtar, K.; Omer, M.; Azeem, S. Characterization of the sludge deposits in crude oil storage tanks. J. Fac. Eng. Technol. 2016, 29, 482-485.

11. Imohimi, A.; Enweani, I.; Eguavoen, O. Characterization and Treatment of Sludge from the Petroleum Industry. Afr. J. Biotechnol. 2006, 5, 461-466.

12. Helmy, Q.; Kardena, E. Petroleum Oil and Gas Industry Waste Treatment; Common Practice in Indonesia. J. Pet. Environ. Biotechnol. 2015, 6, 241. [CrossRef]

13. Ul Haq, I.; Ahmad, W.; Ahmad, I.; Yaseen, M. Photocatalytic oxidative degradation of hydrocarbon pollutants in refinery wastewater using $\mathrm{TiO}_{2}$ as catalyst. Water Environ. Res. 2020, 92, 2086-2094. [CrossRef] [PubMed]

14. Bacosa, H.; Suto, K.; Inoue, C. Preferential degradation of aromatic hydrocarbons in kerosene by a microbial consortium. Int. Biodeteriorat. Biodegrad. 2010, 64, 702-710. [CrossRef]

15. Di Toro, D.M.; McGrath, J.A.; Stubblefield, W.A. Predicting the toxicity of neat and weathered crude oil: Toxic potential and the toxicity of saturated mixtures. Environ. Toxicol. Chem. 2007, 26, 24-36. [CrossRef]

16. Farhad, N.; Hoag, G.E.; Liu, S.; Carley, R.J.; Zack, P. Detection and remediation of soil and aquifer systems contaminated with petroleum products: An overview. J. Pet. Sci. Eng. 2000, 26, 169-178. 
17. Ekundayo, E.O.; Obuekwe, C.O. Effects of an oil spill on soil physico-chemical properties of a spill site in a Typic Paleudult of midwestern Nigeria. Environ. Monit. Assess. 1997, 45, 209-221. [CrossRef]

18. Yavari, S.; Malakahmad, A.; Sapari, N.B. A Review on Phytoremediation of Crude Oil Spills. Water Air Soil Pollut. 2015, $226,279$. [CrossRef]

19. Amro, M.; Benzagouta, M.; Karnanda, W. Investigation on crude oil penetration depth into soils. Arab. J. Geosci. 2011, 6, 873-880. [CrossRef]

20. Pazoki, M.; Hasanidarabadi, B. Management of toxic and hazardous contents of oil sludge in Siri Island. Glob. J. Environ. Sci. Manag. 2017, 3, 33-42. [CrossRef]

21. Tanzharikov, P.; Erken, A.; Abilbek, Z.; Sarabekova, U.; Ermukhanova, N. The technology of preparation of the oil sludge pit with polymerorganic screen for oil waste. ARPN J. Eng. Appl. Sci. 2018, 6, 14.

22. Kuwayama, Y.; Roeshot, S.; Krupnick, A.; Richardson, N.; Mares, J. Pits versus Tanks: Risks and Mitigation Options for On-Site Storage of Wastewater from Shale Gas and Tight Oil Development; Resources for the Future: Washington, DC, USA, $2016 ;$ p. 65.

23. Park, I.; Park, J. A novel total petroleum hydrocarbon fractionation strategy for human health risk assessment for petroleum hydrocarbon-contaminated site management. J. Hazard. Mater. 2010, 179, 1128-1135. [CrossRef] [PubMed]

24. Daučík, P.; Višňovský, J.; Ambro, J.; Hájeková, E. Temperature dependence of the viscosity of hydrocarbon fractions. Acta Chim. Slovaca 2008, 1, 43-57.

25. Chang, W.; Dyen, M.; Spagnuolo, L.; Simon, P.; Whyte, L.; Ghoshal, S. Biodegradation of semi- and non-volatile petroleum hydrocarbons in aged, contaminated soils from a sub-Arctic site: Laboratory pilot-scale experiments at site temperatures. Chemosphere 2010, 80, 319-326. [CrossRef] [PubMed]

26. Yaron, B.; Sutherland, P.; Galin, T.; Acher, A.J. Soil pollution by petroleum products, II. Adsorption-desorption of "kerosene" vapors on soils. J. Contam. Hydrol. 1989, 4, 347-358. [CrossRef]

27. Madadian, E.; Gitipour, S.; Amiri, L.; Alimohammadi, M.; Saatloo, J. The application of soil washing for treatment of polycyclic aromatic hydrocarbons contaminated soil: A case study in a petrochemical complex. Environ. Progress Sustain. Energy 2014, 33, 107-113. [CrossRef]

28. Bykova, M.V.; Alekseenko, A.V.; Pashkevich, M.A.; Drebenstedt, C. Thermal desorption treatment of petroleum hydrocarboncontaminated soils of tundra, taiga, and forest steppe landscapes. Environ. Geochem. Health 2021, 43, 2331-2346. [CrossRef]

29. Qin, J.; Lin, C.; Almebayedh, H.; Albader, M. Decomposition of long-chain petroleum hydrocarbons by Fenton-like processes: Effects of ferrous iron source, salinity and temperature. Ecotoxicol. Environ. Saf. 2019, 169, 764-769. [CrossRef]

30. Sarkar, D.; Ferguson, M.; Datta, R.; Birnbaum, S. Bioremediation of petroleum hydrocarbons in contaminated soils: Comparison of biosolids addition, carbon supplementation, and monitored natural attenuation. Environ. Pollut. 2005, 136, 187-195. [CrossRef]

31. Lu, M.; Zhang, Z.; Qiao, W.; Wei, X.; Guan, Y.; Ma, Q.; Guan, Y. Remediation of petroleum-contaminated soil after composting by sequential treatment with Fenton-like oxidation and biodegradation. Bioresour. Technol. 2010, 101, 2106-2113. [CrossRef]

32. Huguenot, D.; Mousset, E.; Van Hullebusch, E.D.; Oturan, M.A. Combination of surfactant enhanced soil washing and electrofenton process for the treatment of soils contaminated by petroleum hydrocarbons. J. Environ. Manag. 2015, 153, 40-47. [CrossRef] [PubMed] 